\title{
The Omniplus Ultra
}

\section{You can't live without it.}

\section{Paul Di Filippo}

Everyone wants an Omniplus Ultra, and I am not immune to the urge. But of course they are almost impossible to purchase for love or money.

Since their debut nine months ago at the annual Consumer Electronics Show, more than 40 million units have been sold worldwide, exhausting the initial stockpile but barely sating a fraction of consumer demand. The Chinese factories that produce the Omniplus Ultra are tooling up as fast as possible to make more, but retailers cannot guarantee delivery any sooner than six months. On eBay, each available Omniplus Ultra, with a MSRP of \$749.99, sells for upwards of $\$ 5,000$.

OmninfoPotent Corporation, the enigmatic firm behind the Omniplus Ultra, has leapt to the top of the NASDAQ exchange. Its reclusive founders, Pine Martin and Sheeda Waxwing, have vaulted into the lower ranks of the Forbes 400 . Sales of the device are being credited with jump-starting the ailing economy almost single-handedly.

The ad campaign for the Omniplus Ultra has already won six Clios. The catchy theme music, $O U$ Kidz by the Black Eyed Peas, and the images of average people of every race, age, gender, nationality and creed using their Omniplus Ultras to navigate a plethora of life situations ranging from sweetly comic to upliftingly tragic have generated their own fan clubs, YouTube mash-ups and punchlines for late-night comedians. Allusions to the Omniplus Ultra, as well as its invocation in metaphors, similes, rants, raves, jeremiads and paeans, fill watercooler conversations and the printed pages of the world's magazines, newspapers and blogs. The first instant book on the Omniplus Ultra - Uberpower! by Thomas Friedman and Charles Stross - is due out any day.

I myself do not know anyone who actually owns an Omniplus Ultra, but I'm dying to see and handle one. But even 40 million units, distributed across 7 billion people, means that there is only one Omniplus Ultra for every 175 citizens. Of course, the gadgets are not seeded evenly around the planet. They are concentrated in the hands of relatively wealthy and elite consumers and early adopters: circles I do not really travel in, given my job in a Staples warehouse and a set of friends whose familiarity with the latest products of Silicon Valley generally extends no further than their TV remotes.

So I must content myself with studying the advertisements and the gadget-porn reviews. These can't say enough about the life-changing capabilities of the Omniplus Ultra, its potential to shatter all old paradigms and to literally remake the world.

Publisher's Weekly: After five centuries, the printed book has found its worthiest successor in the Omniplus Ultra. The future of reading is safely triumphant.

The Huffington Post: Opens new channels for the spread of democracy.

Boing-Boing: Coolest gadget since the iPhone! The cold-laser picoprojector alone is worth the cost.

Car and Driver: Jack the Omniplus Ultra
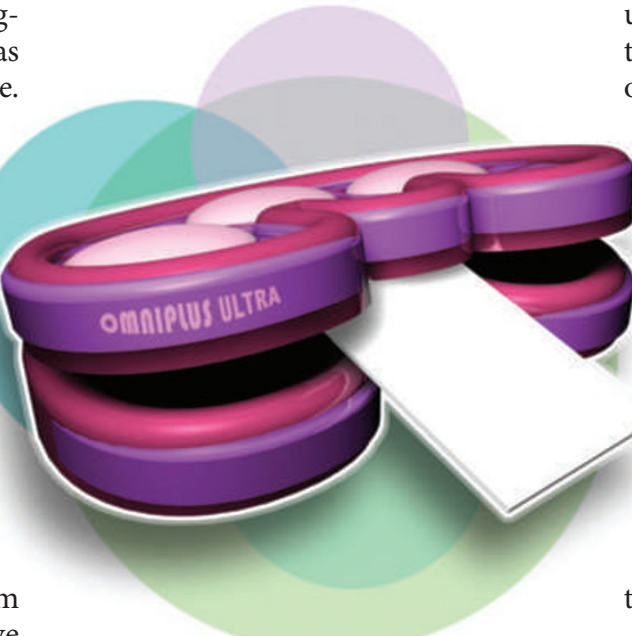

into your dash's USB port and driving will never be the same!

Entertainment Weekly: If you can't download your favourite show onto your Omniplus Ultra, it's not worth watching.

Variety: First flicks helmed with the Omniplus Ultra to hit big screens soon!

Aerospace \& Defense Industry Review: Guaranteed to be standard equipment for all future warriors.

Mother Jones: The Omniplus Ultra is the greenest invention since the Whole Earth Catalog.

Business Week: Every chief executive will benefit from having an Omniplus Ultra to hand - and anyone without one will watch competitors eat their lunch.

Rolling Stone: Elvis. The Beatles. The Sex Pistols. The Omniplus Ultra. The sequence is complete at last.

The more such talk I read, the longer I drool over pictures of the sleekly tactile Omniplus Ultra, with its customizable sexy skins and ergonomically perfect controls, and the more I lust to own one. Although nothing in my condition has really changed, and although I have enough money, love and security, my life feels incomplete and empty without an Omniplus Ultra.

But there was just no way for me to get my hands on one.

Until I saw my boss's boss's boss walk through the warehouse carrying one.

Then and there, I knew what I had to do.

As a low-level employee, I certainly could not jump several levels of management and directly approach my boss's boss's boss and ask to fondle his Omniplus Ultra. But I had a scheme.

It took me six frustrating weeks, but at last I managed it. In a series of furtive unauthorized forays into executive territory, I caught the lucky Omniplus Ultra owner in a lavatory break with his prized possession carelessly left behind on his desk.

That's when I pulled the fire alarm.

While everyone else rushed outside, I darted into the guy's office, snatched his Omniplus Ultra off the desk, and sank down behind the furniture in the knee well, out of sight.

With trembling hands I sought to shuffle aside the protective wings of the device, utilizing all the instructions I had lovingly memorized, and expose its intimate control and display surfaces to my wanton gaze and lewd touch.

But I was doing something wrong! The expected blossoming failed to happen.

Instead, after some fumbling, the unit split open like a simple styrofoam clamshell container full of leftovers.

The interior gaped utterly vacant, except for a simple piece of printed cardboard.

Dumbfounded, I removed the cardboard and read the message.

Dear Consumer: the Omniplus Ultra is not what you need. You are already everything you thought it could do. Pass this message on as widely as you see fit. Or not. Hopefully yours, Pine Martin and Sheeda Waxwing, for the OmninfoPotent Corporation.

I put the card back inside, resealed the Omniplus Ultra, dropped it with a dull thud on the desk, and joined all my peers outside, waiting to resume our lives.

Paul Di Filippo's new novel, Roadside Bodhisattva, will be available in spring 2010. He continues to review for various venues. Join the discussion of Futures in Nature at go.nature.com/QMAm2a 